\section{Social Work \& Education}

CSW\&E, 2021

УДК 378:81’25-057]:07

DOI: $10.25128 / 2520-6230.21 .4 .6$

\section{Інна Анастасія}

\section{Дзюбановська,}

Тернопільський національний педагогічний університет

ім. В. Гнатюка,

м. Тернопіль, вул. Кривоноса, 2,

Україна;

e-mail: dziubanovska@tnpu.edu.ua

ORCID ID: https://orcid.org/0000-

0001-9978-1334

\section{Тетяна Цепенюк,}

Тернопільський національний педагогічний університет

ім. В. Гнатюка

м. Тернопіль, вул. Кривоноса, 2,

Україна;

e-mail: tsepeniuk@gmail.com

ORCID ID: https://orcid.org/

0000-0002-8974-6436

\section{Ірина Ваврів,}

Тернопільський педагогічний ім. В. Гнатюка

м. Тернопіль, вул. Кривоноса, 2,

Україна;

e-mail: iryna.vavriv@gmail.com

ORCID ID: https://orcid.org/

0000-0003-0554-3357

\section{Cmamyc cmammi:}

Отримано: жовтень 25, 2021

1-иеремензувания: листопад 17, 2021

Прийнято: грудень 30, 2021

національний університет
Дзюбановська, І.А., Цепенюк, Т., Ваврів, I. (2021). Фахова компетентність майбутніх вихователів: теоретичні підходи до іï формування на засадах компетентісного підходу. Social Work and Education,

Vol. 8, No. 4. pp. 494-504. DOI: $10.25128 / 2520-$

6230.21.4.6.

\title{
ЗАСТОСУВАННЯ МЕДІАОСВІТНІХ ЕЛЕМЕНТІВ У ПІДГОТОВЦІ МАЙБУТНІХ ПЕРЕКЛАДАЧІВ
}

\begin{abstract}
Анотація. Стаття присвячена висвітленню питання інтеграції інфомедійної грамотності в навчальний контент у процесі підготовки майбутніх перекладачів. У праці наведено чинники, які визначають необхідність застосування медіаосвітніх елементів в освітньому процесі, і на основі проведеного аналізу теоретичних джерел описано поняття i структуру інфомедійної грамотності. Авторами запропоновано комплекс вправ, які спрямовані на формування $\mathrm{i}$ розвиток навичок критичного мислення, інформаційної і цифрової грамотності, соціальної толерантності, креативності здобувачів ОП «Англійсько-український переклад».

Ключові слова: медіаосвіта; інфомедійна грамотність; критичне мислення; цифрова грамотність; соціальна толерантність; освітній процес; інтеграція медіаграмотності.
\end{abstract}

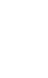




\section{Вступ}

3 розвитком технологій та глобалізацією інформаційного простору дедалі більшої уваги в освіті приділяють проблемам медійної грамотності. Проте, прагнення освітян розвивати свідоме споживання інформації націлене здебільшого на школярів та навіть дітей дошкільного віку, адже вважається, що молодь та дорослі самостійно здатні аналізувати та розрізняти інформаційне середовище навколо них. Багато науковців не погоджуються 3 цим твердженням, a П. Луковський взагалі порівнює вплив інформації на молодь 3 впливом промислових токсинів на річку [5, с. 150]. Він переконаний, що інформаційне забруднення може впливати на індивіда чи групу індивідів протягом тривалого часу, або й взагалі здійснювати неспинний вплив на життя людини глобально.

Так, технічні досягнення, розвиток медійного простору, збільшення кількості інформаційних джерел та доступу до них, а також зовнішні чинники, такі як приналежність до певних соціальних груп чи карантинні обмеження під час пандемії, створюють лавиноподібне збільшення інформації в мережі, часто хаотичне та неконтрольоване, i як наслідок може згубно впливати на непідготовленого споживача незалежно від віку. Більше того, інформатизація суспільства відбувається не окремо чи лише в певних сферах нашого життя, а системно та повномірно захоплює побут, професійну сферу, освітній та виховний процес тощо. Такий стан речей ставить перед сучасним викладачем 3ВО низку викликів.

Перш за все, інформатизація освіти впливає на розуміння навчального процесу, акцентуючи на особистісному підході до роботи зі студентом та створює такі умови навчання, де самостійна робота студента стає ключовим етапом закріплення вмінь та навичок. По-друге, здобувачі освіти повинні усвідомити, що вони одночасно виступають і споживачами інформації, і iї творцями, що повинно збільшити їхнє розуміння власної відповідальності як учасників інформаційного поля. У такому контексті майбутні перекладачі, як інтерпретатори смислових повідомлень, культурних та етичних цінностей несуть значно більшу відповідальність, аніж представники інших професій.

Такі чинники зумовлюють необхідність інтегрувати медіаосвітні елементи та широко використовувати вправи на розвиток критичного мислення задля підвищення рівня медійної грамотності серед студентства. Це забезпечить систематичний підхід здобувачів вищої освіти до усвідомлення свого інформаційного середовища, розуміння впливу ЗМІ та соціальних мереж на соціум, допоможе ухвалювати свідомі та обгрунтовані рішення під час професійної діяльності та у щоденному житті.

Мета цієї статті - продемонструвати механізми використання медіаосвітніх елементів під час вивчення професійно-орієнтованих дисциплін задля формування компетентностей інфомедійної грамотності у майбутніх перекладачів.

\section{Аналіз літератури}

Впродовж останніх десятиліть питання інфомедійної грамотності вивчалось багатьма як зарубіжними, так i вітчизняними науковцями. Різні аспекти 
медіаосвіти крізь призму порівняльної педагогіки вивчали Д. Бачинський, Н. Габор, Дж. Пандженте, Р. Шепард. Особливості підготовки освітян до використання сучасних засобів та методів медінавчання досліджували I. Наумук, Д. Бішоп, Л. Мастерман, К. Браянт. Над питаннями про міждисциплінарні аспекти розвитку освіти працювали Г. Онкович, Б. Потятинник, Е. Бакінгем, Е. Томанн.

Значення інфомедійної освіти сучасної вищої школи важко переоцінити. Її потенціал значно більший, аніж розуміння інформації з гаджетів чи теле- i радіомовлення. За Т. Коноваленко та Ю. Надольською медіаосвіта це - «процес розвитку особистості крізь призму засобів масової комунікації (медіа) з метою формування культури спілкування, навігації в інформаційному просторі, розвитку творчих, комунікативних здібностей, критичного мислення, умінь повноцінного сприйняття, інтерпретації, аналізу й оцінювання медіатекстів, навчання різних форм самовираження за допомогою сучасних інформаційно-комунікаційних технологій $[2$, с. 188$] »$.

За визначенням нової редакції «Концепції впровадження медіаосвіти в Україні» медіаосвіта це - «частина освітнього процесу, спрямована на формування в суспільстві медіакультури, підготовку особистості до безпечної та ефективної взаємодії із сучасною системою мас-медіа, включаючи як традиційні (друковані видання, радіо, кіно, телебачення), так і новітні (комп’ютерно опосередковане спілкування, інтернет, мобільна телефонія) медіа з урахуванням розвитку інформаційно-комунікаційних технологій [3]».

I якщо в Україні медіаосвіта лише набирає обертів, то західні педагоги досить активно використовують медійні концепції, що базуються на чітко окреслених принципах медійної освіти. Саме ці теоретичні принципи визначають не лише зміст, а й чітко формують структуру та цілі медіаосвітньої практики. У нашій розвідці посилатимемося на п'ять ключових принципів медіаосвіти, сформованих Американським центром медійної грамотності (Center for Media Literacy):

1) усі медіаповідомлення $\epsilon$ «сконструйованими»;

2) у медіаповідомленнях креативно використовується мова 3 iï власними правилами;

3) різні люди сприймають одне й те ж медіаповідомлення по-різному;

4) медіа, насамперед, $є$ бізнесом, мета якого - отримати прибуток;

5) медіа містять цінності та відповідні точки зору [6].

Більше того, згодом дослідниця Е. Томан запропонувала аналіз текстів медіа дискурсу, що корелює 3 цими принципами. Аналіз включає чотири основних компоненти: знання - аналіз - рефлексія - дія. Їх науковиця назвала моделлю навчання медійної грамотності [6].

\section{Виклад основного матеріалу}

Опираючись на досвід американських дослідників можемо прослідкувати, що медіаосвіта націлена передусім на особистісний розвиток та формування компетенцій необхідних для гармонійного та свідомого споживання інформації, тобто ставить перед собою завдання розвивати навички медійної грамотності. 
За твердженнями канадських науковців медіаграмотність, як результат якісної медіаосвіти, не $\epsilon$ категорійним поняттям, тобто дослідники унеможливлюють існування цілком необізнаних людей в сфері медіа, як i повністю усвідомлених медіа-споживачів. Вони наголошують, що «медіаграмотність - це результат медіа-освіти, вивчення медіа. Чим більше людина вивчає медіа (за допомогою медіа ресурсів), тим більше вона медіаграмотна, тобто медіаграмотність - це здатність експериментувати, інтерпретувати, аналізувати та створювати медіатексти [7]».

Американські учені стверджують, що бути медіаграмотним означає «бути здатним оптимально використовувати відповідну інформацію, зберігаючи іiі розумно, й ділитися нею з іншими [4]». Це доводить, що медійну грамотність можна і потрібно розвивати та постійно підтримувати навички розуміння свого інформаційного поля.

До компетентностей, що разом складають інфомедійну грамотність, відносяться

1) медіаграмотність;

2) критичне мислення;

3) соціальна толерантність;

4) стійкість до впливів, фактчекінг;

5) інформаційна грамотність;

6) цифрова безпека;

7) візуальна грамотність;

8) інноваційність, розвиток креативності [1].

Завдання сучасного педагога вищої школи формувати ту чи іншу компетенцію або сукупність компетенцій інфомедійної грамотності, інтегруючи ïx, зокрема, у профільні предмети.

У навчальному плані за освітньою програмою «Англійсько-український переклад» у Тернопільському національному педагогічному університеті імені Володимира Гнатюка передбачено вивчення навчальних дисциплін «Основи медіаграмотності» $\mathrm{i}$ «Критичне мислення перекладача», проте викладачі кафедри теорії і практики перекладу також розвивають медійну грамотність студентів і під час вивчення інших профільних предметів, як от «Практичний курс англійської мови», «Вступ до перекладознавства», «Теорія перекладу», «Порівняльна лексикологія англійської та української мов» тощо. Зауважмо, що ідеї інтегрувати інфомедійну грамотність в навчальні матеріали колектив авторів завдячує участі в освітньому проєкті «Вивчай i розрізняй: інфомедійна грамотність», який виконувався Радою міжнародних наукових досліджень та обмінів (IREX) за підтримки Посольств США та Великої Британії, у партнерстві з Міністерством освіти і науки України та Академією Української преси. Розгляньмо комплекс вправ, виконання яких спрямоване на розвиток інфомедійної грамотності у майбутніх перекладачів.

1. Вирава "Сніжинка». Цю вправу виконують мовчки із заплющеними очима. Студенти виконують певні дії з аркушем паперу відповідно до вказівок викладача, який навмисне говорить швидко, моделюючи цим ситуації, які вимагають прийняття швидких рішень, робить помилки у вказівках, що нагадує 
отримання нами неточної інформації. Наприкінці студенти розгортають свої аркуші і демонструють один одному свої вироби - «сніжинки», які у кожного виходять різними. Далі учасники обговорюють, чому кожен отримав різний результат, якщо вказівки для всіх були однаковими. Ця вправа вчить здобувачів освіти розуміти, що в ситуаціях, коли немає можливості перевірити, уточнити інформацію, ми сприймаємо іï по-різному i, як результат, приймаємо різні рішення. Виконання цієї вправи вчить студентів надалі бути уважним до повідомлень у медіапросторі i, отримуючи певну інформацію, шукати підтвердження їі достовірності.

2. Вирава «Знайомство: Ми та Я». Ефективною ця вправа може бути для студентів-першокурсників, завдяки якій вони матимуть можливість познайомитися один з одним, представивши про себе унікальні факти. Студенти за 10 хвилин спілкування у невеликих групах повинні обговорити і представити на аркуші 5 ознак, які $є$ спільними для них, і по 3 унікальні факти про кожного 3 них. Ці ознаки і факти повинні поєднатися у вигляді фігури, де $є$ спільна частина i 5 частин з іменами учасників. Як правило, це може бути квітка, дерево $з$ гілками, сонце 3 промінцями. Викладачу важливо не наголошувати на різниці між ознаками і фактами. Доволі часто учасники освітнього процесу допускаються помилок при виконанні цієї вправи, замість фактів про себе повідомляють суб'єктивні судження, на кшталт «Я добре готую», «Я гарно співаю» замість «Минулого літа я взяла участь у волонтерському проєкті» тощо. Ця вправа має медіаосвітній ефект і демонструє, що для нашої самопрезентації важливі і факти, i судження, і оцінки. Вміння розрізняти факти від суджень $є$ базовою навичкою медіаграмотності.

3. Вирава "Барометр» спрямована на формування у студентів вміння висловлювати свою точку зору з приводу події, твердження, використовуючи аргументацію. Як приклад, під час вивчення теми «Перекладність i неперекладність» на заняттях зі «Вступу до перекладознавства» студентам можна запропонувати висловити свою думку щодо підходів до перекладності: викладач на дошці малює умовну лінію барометра, або ж використовує готовий рисунок, i пише на ній зліва направо варіанти відповідей:

- «Підтримую лише прибічників універсалістського підходу»,

- «Підтримую більше прибічників універсалістського, аніж релятивістського підходу»,

- «50 на 50»,

- «Підтримую більше прибічників релятивістського, аніж універсалістського підходу»,

- «Підтримую лише прибічників релятивістського підходу».

Далі студенти на стікерах пишуть свої прізвища i прикріплюють їх навпроти твердження, яке підтримують. Викладач обов'язково просить студентів прокоментувати свій вибір і аргументувати його.

4. Вирава «SWOT-аналіз» є ефективним інструментом для проведення аналізу певного явища, події тощо. Використовується цей метод у різних галузях - від економіки до психології, результативним є також його використання і в освітній сфері. Цей метод допомагає здобувачам вищої освіти навчитися 
визначити сильні (strengths) і слабкі (weaknesses) сторони певного явища, описати можливості (opportunities) і оцінити загрози (threats). Автори статті при вивченні теми «Особистість» на заняттях 3 «Практичного курсу англійської мови» пропонують першокурсникам за допомогою SWOT-аналізу проаналізувати якості і характеристики своєї особистості - описати свої сильні риси, слабкі якості, над якими слід попрацювати, виокремити зовнішні фактори, які можуть або сприяти особистісному зростанню, або ж становити загрози цьому. На рис. 1 зображено результати SWOT-аналізу використання штучного інтелекту в освіті, проведеного магістрантами 1 року навчання на заняттях 3 «Практичного курсу англійської мови» за допомогою онлайн-дошки scrumblr.

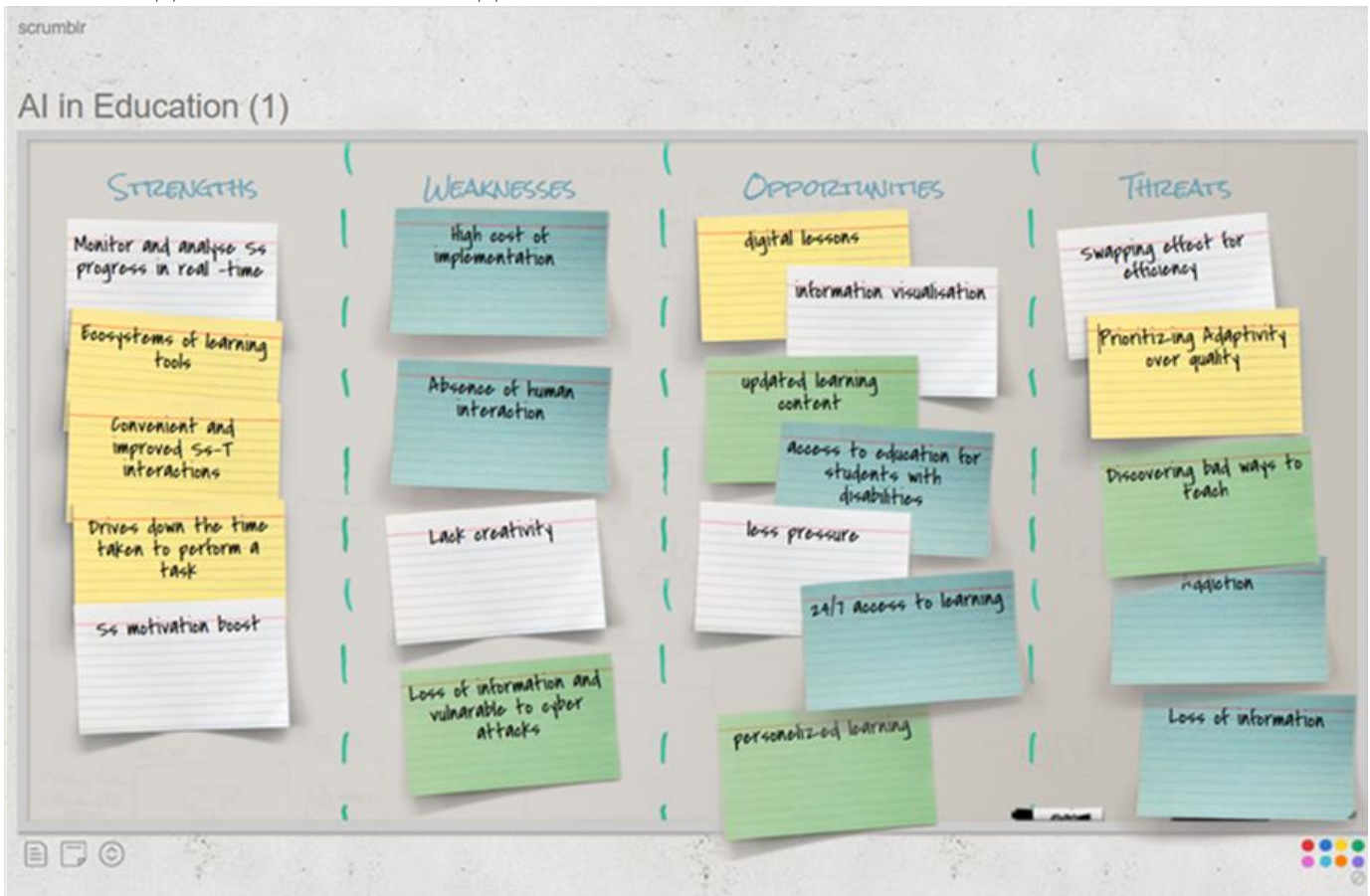

Рис. 1: SWOT-аналіз використання штучного інтелекту в освіті

5. Вирава «Асоціації». Сьогодні спостерігаємо глобальну тенденцію до формування толерантного ставлення учасників освітнього процесу до представників різних соціальних груп і етнічних спільнот задля забезпечення ефективної безбар'єрної комунікації. Актуальним також $\epsilon$ питання про руйнування певних стереотипів і міфів. Зазначена вправа якраз і має на меті сформувати у студентів вміння ідентифікувати власні стереотипи, протистояти їм i сформувати навички толерантності i етичного спілкування, які $\epsilon$ вкрай важливими для перекладачів як медіаторів між представниками різних мов $\mathrm{i}$ культур. На занятті викладач демонструє студентам приклади розповсюджених стереотипів, які пов'язані 3 темою заняття. Далі студенти аналізують свої уявлення про ці стереотипи і критично їх осмислюють. Після цього всі учасники обговорюють вплив медіа на формування наших уявлень і роль ЗМІ у створенні 
стереотипів. Обговоривши наслідки існування дискримінації, студенти спільно 3 викладачем створюють алгоритм протидії стереотипам і міфам.

6. Вирава «Аналіз історичних фото». Під час вивчення теми «Гендерна рівність» студентам було запропоновано виконати цю вправу, яка передбачала аналіз запропонованої фотографії (рис. 2) відповідно до наведеного алгоритму і заповнення таблиці з такими рубриками: «Сюжет фото (що зображено)», «Герої зображення (хто ці люди, чим займаються на фото)», «Подія (що ще відомо)». Така вправа формує в учасників освітнього процесу вміння працювати 3 візуальним матеріалом як джерелом інформації, самостійно здійснювати пошук інформації, спиратися на вже раніше відомі факти, аналізувати історичні події через візуальні матеріали, виявляти фотопідробки та інші маніпулятивні ефекти зображення.

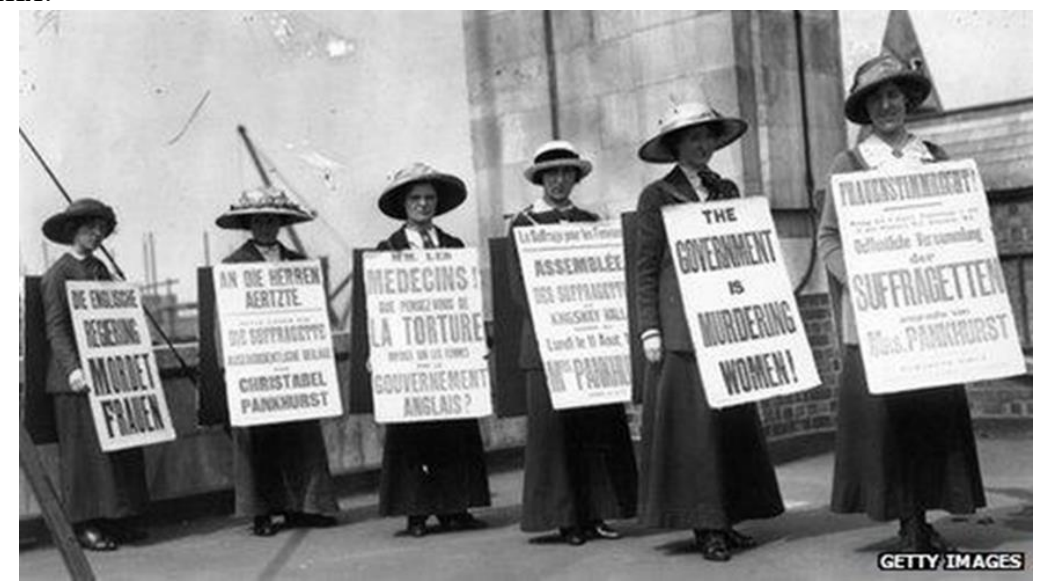

Рис. 2: Суфражистки на демонстрації за права жінок

7. Вирава «Піктограми». Мета цієї вправи полягає в тому, щоб показати учасникам освітнього процесу, наскільки візуалізація (фотографії, ілюстрації, піктограми, інфографіка, схеми) сприяє засвоєнню інформації. Першокурсникам кафедри теорії i практики перекладу на заняттях зі «Вступу до перекладознавства» пропонується створити піктограми до клятви перекладача. Доцільним є виконання вправи і на заняттях 3 «Практичного курсу англійської мови», на яких можна створювати піктограми при обговоренні статей конституцій США і України, або ж при вивченні теми «Мистецтво» студенти створюють піктограми для правил поведінки у театрі чи музеї.

8. Вирава "Створення власного медіаповідомлення». Ця вправа може передбачати виконання різноманітних завдань, як от створення у соцмережах сторінок відомих перекладознавців, авторів або героїв художніх творів, історичних постатей, висвітлення певних подій у медіа під різними кутами тощо. Сьогодні все частіше у засобах масової інформації ми натраплясмо на різноманітні рейтинги за топовими ознаками, однак, навряд чи часто задумуємося над критеріями складання таких рейтингів і над їхнім маніпулятивним ефектом. Майбутнім перекладачам виконання такої вправи може бути особливо корисним, оскільки вона сприяє формуванню критичного мислення і вмінню самостійно шукати і перевіряти необхідну інформацію, також складати чіткі критерії відбору 
до таких рейтингів. Так, студентам можна запропонувати укласти рейтинги за такими топовими ознаками: «Топ-10 міст України, які варто відвідати» (Тема «Україна і українці»), «Топ-10 незвичних страв» (Тема «Їжа»), «Топ-10 сучасних художників», «Топ-10 фільмів про мотивацію» (Тема «Мистецтво»), «Топ-10 визначних перекладачів України» (тема «Історія українського перекладу») тощо.

9. Вирава «Текст про медіа для аналізу». Ця вправа доволі вдало інтегрується в професійно-орієнтовані навчальні дисципліни. Студентам пропонується текст про медіа, у якому вони повинні знайти і прокоментувати відповідно до поставлених завдань певні мовні явища. Завдання 1. Знайдіть в тексті інфінітиви/дієприкметник/герундій, визначте їхню форму $і$ функиії в реченні. Перекладіть иі речення украӥнською мовою, прокоментуйте свій варіант перекладу («Практичний курс англійської мови»). Завдання 2. Знайдіть в тексті інфінітиви/дієприкметник/герундій, визначте їхню форму $і$ функиії в реченні. Перекладіть иі речення украӥнською мовою, прокоментуйте свій варіант перекладу («Теорія перекладу»). Завдання 3. Знайдіть в тексті слова-англіиизми, визначте спосіб їхнього відтворення украйнською мовою. Які з них $\epsilon$ інтернаціоналізмами, а які псевдо-інтернаціоналізмами ("Теорія перекладу»)? Таким чином, при виконанні таких вправ у студентів формуються знання про медійні процеси і явища і при цьому закріплюється матеріал, передбачений програмою навчальної дисциплін.

10. «Підсумкові кадри». Мета використання цієї вправи полягає в тому, щоб актуалізувати отримані знання з певної теми чи цілого курсу, провести підсумки, згадати, систематизувати і закріпити пройдений матеріал. Цю вправу доцільно виконувати по завершенні теми чи всього курсу. Група (клас) розбивається на менші групи, учасники яких на заздалегідь підготовлених аркушах 3 намальованими кадрами 3 кіноплівки малюють у цих кадрах пройдений матеріал. Якщо це систематизація матеріалу, який вивчався впродовж всієї навчальної дисципліни, то кожна група працює над окремою вже вивченою темою. Після закінчення часу (10-15 хв) команди по черзі презентують свої наробки. Учасники 3 інших команд можуть доповнювати і допомагати своїм одногрупникам. Виконання цієї вправи сприяє як кращому засвоєнню інформації, так i налагодженню співпраці у команді. Також така активність демонструє учасникам освітнього процесу, що нерідко ми звертаємо увагу на різні речі та бачимо картину і сприймаємо певну інформацію під іншим кутом.

\section{Висновки}

Якісна підготовка конкурентоспроможних перекладачів у сучасних глобалізованих умовах передбачає формування у них не тільки фахових компетентностей, а й розвиток вмінь і навичок, які дозволили б імм успішно впоратися із викликами сьогодення і сформувати позитивний професійний імідж i суспільний авторитет. Наведені вище вправи дозволять покращити якість підготовки майбутніх перекладачів i сформувати у них навички критичного мислення, інформаційної і цифрової грамотності, соціальної толерантності, креативності. Перспективу подальших досліджень вбачаємо у вивченні 
можливостей інтеграції елементів медіаосвіти в інші професійно-орієнтовані дисципліни у процесі підготовки перекладачів.

\section{Література}

Інтеграція інфомедійної грамотності у навчальний процес. Навчально-методичні матеріали проєкту «Вивчай та розрізняй: інфо-медійна грамотність». К.: IREX в Україні, 2019-2020.

Коноваленко, Т. В., Надольська, Ю. А. (2021). Формування інфомедійної грамотності студентів на заняттях із фахових дисциплін. Інфомедійна грамотність невід'ємна складова навчального процесу закладу вищзӧ освіти. с. 187-194.

Концепція впровадження медіаосвіти в Україні (нова редакція). URL: https://ms.detector.media/mediaosvita/post/16501/2016-04-27-kontseptsiyavprovadzhennyamediaosviti-v-ukraini-nova-redaktsiya/

Aufderheide, P., Firestone, C. (1993). Media Literacy: A Report of the National Leadership Conference on Media Literacy. Queenstown, MD: The Aspen Institute.

Łukowski, P. (2018). Oddziaływanie medialnie kreowanym tłem. Recepcja mediów T. 5. Recepcja mediów przez młodzież w wieku szkolnym i przez osoby dorosłe. Lublin: UMCS. P. 145-152.

Thoman, E. Skills and Strategies for Media Education. URL: http://www.medialit.org/reading-room/skills-strategies-media-education

Worsnop, C. (1996). Assessing Media Work. Mississauga: Wright Communication. 80 p. 


\section{USING MEDIA EDUCATIONAL ELEMENTS WHILE TEACHING FUTURE TRANSLATORS}

Inna Anastasiia Dziubanovska, Assistant of the Department of Theory and Practice of Translation, Ternopil Volodymyr Hnatyuk National Pedagogical University, Ternopil, Ukraine;

Tetiana Tsepeniuk, Head of the Department of Theory and Practice of Translation, Ternopil Volodymyr Hnatiuk National Pedagogical University, Ternopil, Ukraine;

Ірина Ваврів, Assistant of the Department of Theory and Practice of Translation, Ternopil Volodymyr Hnatiuk National Pedagogical University, Ternopil, Ukraine;

Abstract. Media literacy is one of the key competencies a modern person needs to develop alongside with other professional competencies. This article discusses the issue of integrating infomedia literacy into the learning content while preparing future translators. Students need to realize that they are both consumers and creators of information, which should increase understanding of their own responsibilities as participants in the information field. Considering this, future translators, as interpreters of semantic messages, cultural and ethical values, have a much greater responsibility than representatives of other professions. Such factors necessitate the integration of media education elements and the widespread use of exercises to develop critical thinking aimed at increasing the level of media literacy among students. This will ensure a systematic approach of students to understanding their information environment, understanding the impact of media and social networks on society, will help to make sound and reasonable decisions in their professional activities and in everyday life.

The aim of the article is to demonstrate the mechanisms of using media educational elements while teaching professionally-oriented disciplines for future translators to develop their infomedia literacy competencies.

To be media literate means to be able to appropriately use relevant information, store it wisely, and share it with others. Infomedia literacy consists of the following competencies: media literacy; critical thinking; social tolerance; resistance to influences, fact-checking; information literacy; digital security; visual literacy; innovation, development of creativity. These competencies are developed during the courses "Critical Thinking of Translators" and "Basics of Medialiteracy" that are taught to students majoring in translation and interpretation in Ternopil Volodymyr Hnatiuk National Pedagogical University. However, it is worth mentioning that infomedia literacy should be developed during other professionally-oriented courses, namely "Introduction to Translation Studies", "Theory of Translation", "Contrastive Lexicology", "Practical Course of the English Language". The authors of the article suggest a set of exercises aimed at developing the above-mentioned competencies which will help future translators/interpreters successfully cope with challenges of the modern world and form the positive professional image and public authority. 
Key words: media education; infomedia literacy; critical thinking; digital literacy; social tolerance; learning process; media literacy integration.

\section{References}

Integration of infomedia literacy in the learning process. Educational materials of the project "Very verified: infomedia literacy". K.: IREX in Ukraine, 2019-2020. [in Ukrainian].

Konovalenko, T. V., Nadolska, Yu. A. (2021). Developing infomedia literacy of students while teaching professional courses. Infomedia literacy as an integral component of the learning process in a higher educational institution. P. 187-194. [in Ukrainian].

The framework of implementation of media education in Ukraine. URL: https://ms.detector.media/mediaosvita/post/16501/2016-04-27-kontseptsiyavprovadzhennyamediaosviti-v-ukraini-nova-redaktsiya/ [in Ukrainian].

Aufderheide P., Firestone C. Media Literacy: A Report of the National Leadership Conference on Media Literacy. Queenstown, MD: The Aspen Institute, 1993.

Łukowski P. Oddziaływanie medialnie kreowanym tłem. Recepcja mediów T. 5. Recepcja mediów przez młodzież w wieku szkolnym i przez osoby dorosłe. Lublin: UMCS, 2018. P. 145-152.

Thoman E. Skills and Strategies for Media Education. URL: http://www.medialit.org/reading-room/skills-strategies-media-education

Worsnop C. Assessing Media Work. Mississauga: Wright Communication, 1996. 80 p

Article history:

Received: October 25, 2021

1st Revision: November 17, 2021

Accepted: December 30, 2021 